\title{
Factors influencing males' loyalty toward functional foods during the COVID-19 pandemic
}

\author{
Sik Sumaedi ${ }^{1}$, Sumardjo $^{2}$, Amiruddin Saleh $^{2}$, Agus Fanar Syukri ${ }^{1}$ \\ ${ }^{1}$ National Research and Innovation Agency, South Jakarta, Indonesia \\ ${ }^{2}$ Human Ecology Faculty, IPB University, Bogor, Indonesia
}

\begin{tabular}{l}
\hline Article Info \\
\hline Article history: \\
Received Feb 12, 2021 \\
Revised Nov 5, 2021 \\
Accepted Nov 16, 2021 \\
\hline
\end{tabular}

Keywords:

COVID-19 pandemic

Digital communication

Functional food

Health behaviour

Health education

\begin{abstract}
Coronavirus disease 2019 (COVID-19) is a serious issue nowadays. Several studies showed that male was more vulnerable to COVID-19 than female. Functional food consumption can be used to overcome COVID-19 since it boosts someone's immune system and reduces the risk of contracting noncommunicable diseases simultaneously. It is important to improve males' functional food loyalty during the COVID-19 pandemic. However, there is lack of research on males' functional food loyalty during the COVID-19 pandemic. Given this, this research aims to test the effect of perceived threat of COVID-19, perceived benefit of functional food related to COVID-19, ehealth literacy, digital health communication media usage, attitude toward functional food, functional food accessibility, and social influencesinjunctive norm and descriptive norm-on males' functional food loyalty during the COVID-19 pandemic. This study collected data through a survey. It involved 204 male respondents in Banten, Indonesia. This research found that males' functional food loyalty during the COVID-19 pandemic was significantly and positively affected by attitude toward functional food, injunctive norm, food accessibility and digital health communication usage. However, males' functional food loyalty was not significantly affected by the perceived threat of COVID-19, perceived benefit of functional food related to COVID-19, descriptive norm and e-health literacy.
\end{abstract}

This is an open access article under the $\underline{C C B Y-S A}$ license.

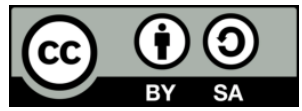

\section{Corresponding Author:}

Sik Sumaedi

National Research and Innovation Agency

Jln. Jend Gatot Subroto No. 10, South Jakarta, 12710, Indonesia

Email: siks002@lipi.go.id, sik_s_01@yahoo.com

\section{INTRODUCTION}

Functional food is a popular topic in health and food literature since it provides many health benefits [1]. Functional food can be exploited by a government to improve the health status of its citizens and decrease its national health cost [1]. Indonesia is one of the countries that have many raw materials that can be processed as functional food [2], [3]. Thus, Indonesia can use functional food as a part of its national health strategy. Nowadays, there is a serious health problem worldwide, namely Coronavirus disease 2019 (COVID-19) pandemic. As of January 17, 2021, there have been 95,429,176 people infected by COVID-19 around the world [4]. Globally, 2,038,559 COVID-19 infected people have died [4]. In Indonesia, The COVID-19 pandemic is also a serious problem. More than nine hundred thousand Indonesians are infected COVID-19 [4] and more than 25 thousand have died due to COVID-19 [4].

To overcome COVID-19, someone must have a good immune system [5]. Furthermore, it is also important to prevent and manage non-communicable diseases (NCDs) since a COVID-19 infected person with NCD would have a worse prognosis compared to a COVID-19 infected person without NCD [6]. 
Related to this issue, functional food consumption might boost someone's immune system and reduce his or her risk of contracting NCDs simultaneously [7]. Therefore, during the COVID-19 pandemic, it is essential to increase the consumption of functional food. In food consumption behaviour literature, a concept that has an important role is loyalty [8]-[13]. Loyalty has been identified as a key success of a business that should be monitored and improved [14]. Someone who has a high loyalty to certain food would consume it more frequently and recommend it to others [8], [10], [11], [13]. Therefore, it is important to monitor and increase loyalty toward functional food (hereinafter referred to as functional food loyalty).

During the COVID-19 pandemic, it was revealed that males were more vulnerable to COVID-19 than female. Several studies showed that the mortality rate of COVID-19 infected males was greater than COVID-19 infected females [15], [16]. This condition indicated the importance of a study to understand males' functional food loyalty during COVID-19 pandemic. Loyalty is a popular topic in consumption behaviour research. In consumption behaviour literature, most of researchers agreed that loyalty was defined as someone's deep commitment to consume something continuously [9], [12], [17]. Furthermore, loyalty generally was measured using two indicators, namely intention to keep consuming and willingness to recommend [8], [10]-[13]. Loyalty could also be measured using consumption frequency [9]. Many researchers have investigated loyalty in various contexts [17]-[21]. However, in the context of functional food consumption research, this study identified several research gaps.

First, there was a lack of functional food consumption research that specifically investigated functional food loyalty. Most previous studies on functional food consumption focused on the awareness or the acceptance of functional food [22]-[28]. Second, there was a lack of research on functional food consumption performed in the context of the COVID-19 pandemic. During the COVID-19 pandemic, based on the health belief model (HBM), two factors might have an essential role in determining someone's functional food loyalty, namely perceived threat of COVID-19 and perceived benefit of functional food related to COVID-19 [3], [29]. Third, functional food can be categorized as healthy food [5]. Based on healthy foods consumption behaviour literature, several factors that might have an essential role in forming someone's functional food loyalty, namely electronic health literacy (e-health literacy) [30], [31], digital health communication media usage [31], [32], attitude toward functional food [33], [34], functional food accessibility [35]-[37], and social influences-injunctive norm and descriptive norm [38], [39]. Unfortunately, no research has developed and tested functional food loyalty model that involved e-health literacy, digital health communication media usage, attitude toward functional food, functional food accessibility, and social influences, descriptive norm and injunctive norm. To fill the research gaps, this research aimed to test: the effect of perceived threat of COVID-19, perceived benefit of functional food related to COVID-19, e-health literacy, digital health communication media usage, attitude toward functional food, functional food accessibility, and social influences-injunctive norm and descriptive norm on males' functional food loyalty during the COVID-19 pandemic.

\section{METHOD}

\subsection{Variables and measures}

This research used nine main variables, namely functional food loyalty, perceived threat of COVID19, perceived benefit of functional food related to COVID-19, electronic health literacy, digital health communication media usage, attitude toward functional food, functional food accessibility, injunctive norm, and descriptive norm. Table 1 shows the definitions and the number of the indicators of the variables. All indicators were measured using a four-point Likert scale.

\subsection{Construct validity and reliability}

This research performed a factor analysis to check the construct validity of the instrument and Cronbach's alpha analysis to test the reliability of the instrument. The construct validity of a variable measurement instrument was confirmed if the instrument fulfilled three requirements: i) the Kaiser-MeyerOlkin (KMO) value equals to or greater than 0.5 , ii) p-value of Bartlett's test of sphericity equals to or lower than 0.05 and iii) the factor loading values for each indicator equals to or greater than 0.5 [40]. The reliability of a variable measurement instrument was confirmed if the Cronbach's alpha coefficient equals to or greater than 0.6 [40], [41]. Table 2 exhibits the results of the construct validity and reliability testing. Based on Table 2, the research instrument was valid and reliable.

\subsection{Sample and data collection}

This research collected data through a field survey using a questionnaire. This research was conducted in Banten, Indonesia. This study selected Banten because it faced two serious health problems, NCD and COVID-19 pandemic, which effects might be minimized by functional food consumption. Since our research involved digital health media communication usage, this study must ensure that the respondents of our research 
were digital health media communication user. Given this, the population of this research was 15 years old or older males Banten residents who have used digital health media communication. The age threshold was selected because 15 years old is acknowledged as the minimum limit of productive age in Indonesia. Therefore, this study expected that the respondents were capable to give an opinion regarding the variables investigated in this research.

Table 1 . The research variable and indicator

\begin{tabular}{|c|c|c|c|c|}
\hline No & Variable & Definition & $\begin{array}{l}\text { Number of } \\
\text { Indicators }\end{array}$ & Adapted from \\
\hline 1 & Functional food loyalty & $\begin{array}{l}\text { Someone's deep commitment to keep consuming } \\
\text { functional food continuously }[9],[12],[17]\end{array}$ & 6 & {$[8],[10]-[13]$} \\
\hline 2 & Attitude toward functional food & $\begin{array}{l}\text { Someone's overall evaluation on the functional } \\
\text { food [40] }\end{array}$ & 6 & [40] \\
\hline 3 & e-Health literacy & $\begin{array}{l}\text { The capability to find, evaluate, and use health } \\
\text { information in the internet [30], [42], [43] }\end{array}$ & 6 & [43] \\
\hline 4 & $\begin{array}{l}\text { Digital health communication media } \\
\text { (DHCM) usage }\end{array}$ & $\begin{array}{l}\text { The frequency of searching for healthy food } \\
\text { information through in the last three months [32], } \\
\text { [42]-[44] }\end{array}$ & 3 & {$[3],[45],[46]$} \\
\hline 5 & Functional food accessibility & $\begin{array}{l}\text { The extent to which a person can easily find and } \\
\text { consume functional food [35]-[37] }\end{array}$ & 6 & [47], [48] \\
\hline 6 & Injunctive norm & $\begin{array}{l}\text { the level of social pressure to consume functional } \\
\text { food felt by someone because important people } \\
\text { around him or her recommended it [27], [49] }\end{array}$ & 2 & [3], [39] \\
\hline 7 & Descriptive norm & $\begin{array}{l}\text { The level of social pressure felt by someone to } \\
\text { consume functional food because important } \\
\text { people around him or her consumed it [27], [49] }\end{array}$ & 2 & [3], [39], [50] \\
\hline 8 & $\begin{array}{l}\text { Perceived benefit of functional food } \\
\text { consumption behaviour related to } \\
\text { COVID-19 }\end{array}$ & $\begin{array}{l}\text { The extent to which a person felt that functional } \\
\text { food consumption benefited him or her in facing } \\
\text { the COVID-19 pandemic [29] }\end{array}$ & 2 & [51] \\
\hline 9 & Perceived threat of COVID-19 & $\begin{array}{l}\text { The extent to which a person felt that COVID-19 } \\
\text { was dangerous for him or her [40] }\end{array}$ & 6 & [3], [40], [52] \\
\hline
\end{tabular}

Table 2 . The validity and reliability testing results

\begin{tabular}{llcccc}
\hline No & \multicolumn{1}{c}{ Variable } & KMO & $\begin{array}{c}\text { Bartlett's test of } \\
\text { sphericity (sig.) }\end{array}$ & $\begin{array}{c}\text { Factor } \\
\text { loading }\end{array}$ & $\begin{array}{c}\text { Cronbach Alpha } \\
\text { Coefficient }\end{array}$ \\
\hline 1 & Functional food loyalty & .861 & .000 & $.886-.927$ & .954 \\
2 & Attitude toward functional food & .844 & .000 & $.750-.871$ & .912 \\
3 & e-Health literacy & .875 & .000 & $.701-.877$ & .907 \\
4 & DHCM usage & .748 & .000 & $.899-.930$ & $.736-.892$ \\
5 & Functional food accessibility & .866 & .000 & .921 & .906 \\
6 & Injunctive norm & .500 & .000 & .902 & .902 \\
7 & Descriptive norm & .500 & .000 & .884 & .719 \\
8 & Perceived benefit of functional food consumption & .500 & .000 & $.771-.843$ & .893 \\
9 & behaviour related to COVID-19 & .797 & .000 & \\
\hline
\end{tabular}

Since the population characteristics were unknown and the survey was performed during the COVID-19 pandemic, there was operational limitation in gathering sample. A purposive sampling technique was performed. The sample criteria used are: i) male, ii) 15 years old or older and iii) has used digital health media communication. The respondents were asked to voluntarily participate in the survey in their houses. The survey recruited the respondents if they fulfilled the sample criteria and agreed to participate in the survey voluntarily. This research obtained 204 respondents. The minimum sample size needed for this research was 195 since this research involved 39 indicators and employed multiple regression analysis that required the minimum sample size of at least five times the number of indicators [3], [40]. Thus, the sample size of this research has fulfilled the requirements. Most of the sample was married (60.8\%), aged 25-34 years old $(27.9 \%)$ and had a senior high school education or equivalent $(84.31 \%)$. Table 3 shows the demographic profile of the sample.

\subsection{Data analysis}

This the research conducted a multiple regression analysis. Multiple regression analysis was selected because the method has been used by many previous studies on loyalty [53], [54]. The goodness of fit of the regression model was assessed using the $\mathrm{F}$ test. The model has a good fit if the model's p-value equals to or less than 0.05 [3], [40], [41]. The impact of the proposed independent variable then was evaluated using the T-test. The significant effect is confirmed if the p-value equals to or less than 0.05 [41]. The data analyses were performed using SPSS. 
Table 3. The sample demographic profile

\begin{tabular}{|c|c|c|c|}
\hline No & \multicolumn{2}{|c|}{ Demographic Profile } & $\%$ \\
\hline \multirow[t]{4}{*}{1} & Age & $15-24$ years old & 23.1 \\
\hline & & 25-34 years old & 27.9 \\
\hline & & $35-44$ years old & 22.6 \\
\hline & & $\geq 45$ years old & 26.4 \\
\hline \multirow[t]{5}{*}{2} & Education & Bachelor degree & 3.43 \\
\hline & & Diploma & 5.39 \\
\hline & & Senior high school & 84.31 \\
\hline & & Junior high school & 5.88 \\
\hline & & Elementary school & 0.98 \\
\hline \multirow[t]{3}{*}{3} & Marital status & Married & 60.8 \\
\hline & & Single & 36.8 \\
\hline & & Divorce & 2.5 \\
\hline \multirow[t]{5}{*}{4} & Occupation & Student & 12.2 \\
\hline & & Entrepreneur & 25.0 \\
\hline & & Private company employees & 38.7 \\
\hline & & Freelance/honorary labor & 12.7 \\
\hline & & Other & 11.4 \\
\hline
\end{tabular}

\section{RESULTS AND DISCUSSION}

\subsection{Results}

Table 4 exhibits the multiple regression analysis results. Based on Table 4, the regression model has a F-value of 154.647 and p-value of 0.000. Thus, the regression model has a good fit. Furthermore, from t-value, p-value, and the regression coefficient of the independent variables in Table 4, it can be stated that males' functional food loyalty during the COVID-19 pandemic was significantly affected by attitude toward functional food, injunctive norm, functional food accessibility and the digital health communication usage. However, males' functional food loyalty was not significantly affected by perceived threat of COVID-19, perceived benefit of functional food related to COVID-19, descriptive norm, and e-health literacy.

Table 4. The multiple regression analysis results

\begin{tabular}{|c|c|c|c|c|c|}
\hline \multirow[t]{2}{*}{ Variable } & \multicolumn{2}{|c|}{$\begin{array}{l}\text { Unstandardized } \\
\text { coefficients }\end{array}$} & \multirow{2}{*}{$\begin{array}{c}\text { Standardized } \\
\text { coefficients } \\
\beta \\
\end{array}$} & \multirow[t]{2}{*}{$\mathrm{t}$} & \multirow[t]{2}{*}{ Sig. } \\
\hline & $\beta$ & Std. Error & & & \\
\hline (Constant) & $1.995 \mathrm{E}-15$ & .026 & & .000 & 1.000 \\
\hline e-health literacy & -.028 & .034 & -.028 & -.820 & .413 \\
\hline Digital health communication media usage & .144 & .043 & .144 & 3.330 & .001 \\
\hline Functional food accessibility & .272 & .037 & .272 & 7.443 & .000 \\
\hline Attitude toward functional food & .560 & .048 & .560 & 11.779 & .000 \\
\hline Perceived threat of COVID-19 & .037 & .029 & .037 & 1.264 & .208 \\
\hline Perceived benefit of functional food related to COVID-19 & .051 & .038 & .051 & 1.339 & .182 \\
\hline Injunctive norm & .105 & .041 & .105 & 2.546 & .012 \\
\hline Descriptive norm & -.023 & .046 & -.023 & -.505 & .614 \\
\hline
\end{tabular}

\subsection{Theoretical Implications}

The first finding revealed that attitude toward functional food influenced males' functional food loyalty positively and significantly. This finding means that more positive attitude on functional food would lead to a higher males' loyalty toward functional food. This finding supported the finding of the previous studies [8], [9], [12], [13]. This research also found that descriptive norm did not significantly affect males' functional food loyalty significantly. This finding did not support the theory of planned behaviour (TPB). Furthermore, this finding was also different with findings from previous studies [13], [55], [56].

The non-significant impact of descriptive norm on males' functional food loyalty might relate to the COVID-19 pandemic situation. Descriptive norm represented the social pressure felt by someone due to others' behaviour [27], [49]. The pressure might be more significant if there were substantial interactions between people. During the COVID-19 pandemic, Indonesian government limited physical interactions, such as group meetings, that could increase social pressures. Furthermore, it is also well known that someone might change his behaviour to get a good image if there was no physical interaction as a verification of his real behaviour. Another explanation might relate to Indonesian communities' familiarity with functional food concept. The concept of functional food that can mitigate the negative effect of COVID-19 was still unpopular in Indonesian community. There was no massive promotion on the usefulness of functional food to help with COVID-19. The ignorance might undermine the value of functional foods during the pandemic and the social pressure to consume them. 
The third finding showed that injunctive norm significantly and positively influenced males' functional food loyalty. The finding indicated that when someone felt that important people around him recommended the consumption of functional food, he would be very likely to be more loyal to functional food. This finding supported TPB. This finding also supported the findings of previous studies [55], [56].

The fourth finding revealed that functional food accessibility positively and significantly influenced males' loyalty functional food. It was highly plausible that easier access to functional food would make someone more loyal to it. This finding holds similar notions with previous study [57].

The fifth finding of this research found that perceived threat of COVID-19 did not significantly influence males' loyalty toward males' functional food loyalty during the COVID-19 pandemic. This finding was a deviation from the HBM, which proposed that the perceived threat of disease positively influenced health behaviour [29]. This finding was also in contrast with finding of the previous studies [58], [59].

The sixth finding showed that perceived benefit of functional food related to COVID-19 did not significantly influence males' functional food loyalty. This finding was poles apart with the proposition of the HBM [29]. This finding was also different from the findings of the previous studies [58], [59].

The non-significant impact of perceived threat of COVID-19 and perceived benefit of functional food related to COVID-19 on males' loyalty toward functional food might correlate with the time lag between the consumption and the effects of consuming functional food and the existence of other available alternatives. The benefit of functional food consumption was not instant [1]. Someone needed to consume functional food consistently to gain significant benefits [3]. In other words, to obtain the benefits of functional food, someone must include it in his healthy diet. On the other hand, someone who perceived COVID-19 as a serious threat would prefer alternatives with more immediate effects against COVID-19. Other alternatives might include supplements or medicines. Therefore, even though someone perceived COVID-19 as a significant threat and understood the benefits of functional foods, he might not intend to consume and recommend them.

The seventh finding revealed that DHCM usage positively and significantly influenced males' functional food loyalty. This finding means that higher frequency of digital health communication media usage would lead to higher functional food loyalty, an association also proposed by the IMeHU [30], [31]. This finding also corroborates the finding of the previous studies [32], [42]-[44].

The eighth finding showed that e-health literacy did not play a significant role in improving males' functional food loyalty. This finding did not support previous studies, such as [30] and [31]. It might be because credible e-health information sources could be easily accessed by all people. In Indonesia, many digital health communication media facilitated health knowledge transfers from doctors to the public. This condition might cause both low- and high-level of e-health literacy man could easily obtain high-quality health information, which led to the reduced impact of e-health literacy on health behaviour, including males' functional food loyalty during the COVID-19 pandemic.

\subsection{Managerial implications}

This research found that males' functional food loyalty was positively and significantly influenced by attitude toward functional food. However, their loyalty was not significantly influenced by the perceived threat of COVID-19 and the perceived benefit of functional food related to COVID-19. Therefore, first, males' attitude toward functional food should be monitored, measured, and improved consistently to strengthen males' functional food loyalty. The public health education program should be developed and performed to build positive attitude toward functional food. Second, to boost the impact of perceived threat of COVID-19 and the perceived benefit of functional food on males' functional food loyalty, it is important to communicate the quickly-obtained benefits of functional food related to COVID-19. It is also important to communicate the advantage of functional food consumption compare with its alternatives, such as multivitamins or individual supplements. Furthermore, it is also important to familiarise consumers the complementary function of functional food with the function of other healthy food and/or supplement.

This research found that injunctive norm has a positive impact on males' functional food loyalty while descriptive norm does not. This finding implied that public health education should involve key social figures or opinion leaders to increase males' functional food loyalty. Key social figures or opinion leaders should spread positive messages on functional food through their platforms. They also need to recommend the functional food consumption during the COVID-19 pandemic. Furthermore, since there was no significant impact of descriptive norm on males' functional food loyalty during COVID-19 pandemic, key social figures or opinion leaders should clearly quote credible health information sources, such as medical or health scientific journals, when they spread and recommend functional food.

This research found that males' loyalty males' functional food loyalty was positively and significantly influenced by digital health communication media usage. Based on this finding, to improve males' functional food loyalty, public health education should utilize digital health communication media. In Indonesia, many digital health communication media are available. The government and Non-Governmental Organizations

Factors influencing males' loyalty toward functional foods during the COVID-19 pandemic (Sik Sumaedi) 
(NGOs) could set up partnerships with the media to improve males' loyalty toward functional food during the COVID-19 pandemic. Furthermore, the government and NGOs could also choose to develop their own digital health communication media. Their public health education extension program should be executed through the media. This education extension approach was known as cyber extension approach [60].

There was a positive and significant impact of functional food accessibility on males' loyalty toward functional food. Based on this finding, it is important to ensure that functional food can be easily accessed. Accessibility meant food availability, affordability, and location accessibility [35]-[37]. Therefore, it is important to ensure adequate supplies of functional food during the COVID-19 pandemic. Furthermore, it is important to make sure that the store locations are easily accessible. It is also important to assure that the prices are affordable and stable during the COVID-19 pandemic.

\section{CONCLUSION}

Males' functional food loyalty during the COVID-19 pandemic was significantly and positively affected by attitude toward functional food, injunctive norm, food accessibility and digital health communication usage. However, males' functional food loyalty was not significantly affected by the perceived threat of COVID-19, perceived benefit of functional food related to COVID-19, descriptive norm and e-health literacy.

In order to improve males' functional food loyalty, it is essential to improve males' attitude toward functional food. It is also important to increase injunctive norm by involving key social figures or opinion leaders in public health education on functional food. It is also important to increase public health education activities through digital health communication media. Furthermore, functional food accessibility should be ensured.

\section{ACKNOWLEDGMENT}

All authors are main contributor of this paper. The authors would also like to thanks to the management of Indonesian Institute of Sciences, the quality management research group and Nidya J. Astrini that have supported this research.

\section{REFERENCES}

[1] S. Iwatani and N. Yamamoto, "Functional food products in Japan: A review," Food Sci. Hum. Wellness, vol. 8, no. 2, pp. 96-101, Jun. 2019, doi: 10.1016/j.fshw.2019.03.011.

[2] T. D. Widyaningsih, N. Wijayanti, and N. I. P. Nugrahini, Functional food: Health, evaluation and regulation aspects (In Indonesia: Pangan fungsional: Aspek kesehatan, eavluasi, dan regulasi). Malang: Universitas Brawijaya Press, 2017.

[3] S. Sumaedi and Sumardjo, "A model of traditional functional food consumption behaviour," Br. Food J., vol. 123, no. 1, pp. 1330, Dec. 2020, doi: 10.1108/BFJ-01-2020-0019.

[4] Worldometer, “COVID-19 Coronavirus Pandemic," 2021. https://www.worldometers.info/coronavirus/ (accessed Jan. 17, 2021).

[5] F. Aman and S. Masood, "How nutrition can help to fight against COVID-19 Pandemic," Pakistan J. Med. Sci., vol. 36, no. COVID19-S4, May 2020, doi: 10.12669/pjms.36.COVID19-S4.2776.

[6] E. Y. Y. Chan et al., "What happened to people with non-communicable diseases during COVID-19: Implications of H-EDRM policies,” Int. J. Environ. Res. Public Health, vol. 17, no. 15, p. 5588, Aug. 2020, doi: 10.3390/ijerph17155588.

[7] B. Han and B. X. Hoang, "Opinions on the current pandemic of COVID-19: Use functional food to boost our immune functions," J. Infect. Public Health, vol. 13, no. 12, pp. 1811-1817, Dec. 2020, doi: 10.1016/j.jiph.2020.08.014.

[8] H.-J. Lee and C. Goudeau, "Consumers' beliefs, attitudes, and loyalty in purchasing organic foods," Br. Food J., vol. 116, no. 6, pp. 918-930, May 2014, doi: 10.1108/BFJ-02-2013-0030.

[9] E. Dorota Rudawska, "Customer loyalty towards traditional products - Polish market experience," Br. Food J., vol. 116, no. 11, pp. 1710-1725, Oct. 2014, doi: 10.1108/BFJ-10-2013-0299.

[10] D. J.-W. Kwun, J. H. Hwang, and T.-H. Kim, "Eating-out motivations and variety-seeking behavior: An exploratory approach on loyalty behavior," J. Hosp. Mark. Manag., vol. 22, no. 3, pp. 289-312, Apr. 2013, doi: 10.1080/19368623.2011.653049.

[11] V. da V. Dias, M. da S. Schuster, E. Talamini, and J. P. Révillion, "Scale of consumer loyalty for organic food," Br. Food J., vol. 118, no. 3, pp. 697-713, Mar. 2016, doi: 10.1108/BFJ-09-2015-0332.

[12] C. Y. Yang and C. H. Yang, "The impact of sustainable environmental management in the food and beverage industry on customer loyalty: A view of brand attitude," Ekoloji, vol. 28, no. 107, pp. 965-972, 2019.

[13] F. K. Rabbanee, T. Afroz, and M. M. Naser, "Are consumers loyal to genetically modified food? Evidence from Australia," Br. Food J., vol. 123, no. 2, pp. 803-819, Nov. 2020, doi: 10.1108/BFJ-11-2019-0832.

[14] S. Molinillo, R. Anaya-Sánchez, and F. Liébana-Cabanillas, "Analyzing the effect of social support and community factors on customer engagement and its impact on loyalty behaviors toward social commerce websites," Comput. Human Behav., vol. 108, p. 105980, Jul. 2020, doi: 10.1016/j.chb.2019.04.004.

[15] A. Pradhan and P.-E. Olsson, "Sex differences in severity and mortality from COVID-19: are males more vulnerable?," Biol. Sex Differ., vol. 11, no. 1, p. 53, Dec. 2020, doi: 10.1186/s13293-020-00330-7.

[16] G. Sharma, A. S. Volgman, and E. D. Michos, "Sex differences in mortality from COVID-19 pandemic," JACC Case Reports, vol. 2, no. 9, pp. 1407-1410, Jul. 2020, doi: 10.1016/j.jaccas.2020.04.027.

[17] V. Kumar, I. D. Pozza, and J. Ganesh, "Revisiting the satisfaction-loyalty relationship: empirical generalizations and directions for future research,” J. Retail., vol. 89, no. 3, pp. 246-262, Sep. 2013, doi: 10.1016/j.jretai.2013.02.001.

[18] I. Bardauskaite, "Loyalty in the business-to-business service context: a literature review and proposed framework," J. Relatsh. Mark., vol. 13, no. 1, pp. 28-69, Jan. 2014, doi: 10.1080/15332667.2014.882628. 
[19] D. van Lierop, M. G. Badami, and A. M. El-Geneidy, "What influences satisfaction and loyalty in public transport? A review of the literature," Transp. Rev., vol. 38, no. 1, pp. 52-72, Jan. 2018, doi: 10.1080/01441647.2017.1298683.

[20] A. Moretta Tartaglione, Y. Cavacece, G. Russo, and G. Granata, "A systematic mapping study on customer loyalty and brand management," Adm. Sci., vol. 9, no. 1, p. 8, Jan. 2019, doi: 10.3390/admsci9010008.

[21] H. Górska-Warsewicz and O. Kulykovets, "Hotel brand loyalty-a systematic literature review," Sustainability, vol. 12, no. 12, p. 4810, Jun. 2020, doi: 10.3390/su12124810.

[22] S. Hasnah Hassan, "Consumption of functional food model for malay muslims in Malaysia," J. Islam. Mark., vol. 2, no. 2, pp. 104-124, Jun. 2011, doi: 10.1108/17590831111139839.

[23] A. Annunziata, A. Mariani, and R. Vecchio, "Consumer understanding and use of health claims: the case of functional foods," Recent Pat. Food. Nutr. Agric., vol. 6, no. 2, pp. 113-126, Mar. 2015, doi: 10.2174/2212798407666150213121543.

[24] M. B. M. Rifnaz, U. K. Jayasinghe-Mudalige, T. P. S. R. Guruge, J. M. M. Udugama, H. M. L. K. Herath, and J. C. Edirisinghe, "Perceived health status of consumers and incorporation of functional ingredients into their diet," Procedia Food Sci., vol. 6, pp. 56-59, 2016, doi: 10.1016/j.profoo.2016.02.011.

[25] M. Siegrist, J. Shi, A. Giusto, and C. Hartmann, "Worlds apart. consumer acceptance of functional foods and beverages in Germany and China," Appetite, vol. 92, pp. 87-93, Sep. 2015, doi: 10.1016/j.appet.2015.05.017.

[26] M. Bazhan, N. Keshavarz-Mohammadi, H. Hosseini, and N. Kalantari, "Consumers' awareness and perceptions regarding functional dairy products in Iran,” Br. Food J., vol. 119, no. 2, pp. 253-266, Feb. 2017, doi: 10.1108/BFJ-06-2016-0270.

[27] D. Barauskaite, J. Gineikiene, B. M. Fennis, V. Auruskeviciene, M. Yamaguchi, and N. Kondo, "Eating healthy to impress: How conspicuous consumption, perceived self-control motivation, and descriptive normative influence determine functional food choices," Appetite, vol. 131, pp. 59-67, Dec. 2018, doi: 10.1016/j.appet.2018.08.015.

[28] D. Guzek, D. Głąbska, M. Sajdakowska, and K. Gutkowska, "Analysis of association between the consumer food quality perception and acceptance of enhanced meat products and novel packaging in a population-based sample of polish consumers," Foods, vol. 9, no. 11, p. 1526, Oct. 2020, doi: 10.3390/foods9111526.

[29] W. Khumros, A. Vorayingyong, S. Suppapitiporn, T. Rattananupong, and V. Lohsoonthorn, "Effectiveness of modified health belief model-based intervention to reduce body mass index for age in overweight junior high school students in Thailand," $J$. Heal. Res., vol. 33, no. 2, pp. 162-172, Mar. 2019, doi: 10.1108/JHR-08-2018-0065.

[30] S. Mitsutake, A. Shibata, K. Ishii, and K. Oka, "Associations of eHealth literacy with health behavior among adult internet users," J. Med. Internet Res., vol. 18, no. 7, p. e192, Jul. 2016, doi: 10.2196/jmir.5413.

[31] S.-C. Yang, Y.-F. Luo, and C.-H. Chiang, "The associations among individual factors, ehealth literacy, and health-promoting lifestyles among college students," J. Med. Internet Res., vol. 19, no. 1, p. e15, Jan. 2017, doi: 10.2196/jmir.5964.

[32] E. Kontos, K. D. Blake, W.-Y. S. Chou, and A. Prestin, "Predictors of eHealth Usage: insights on the digital divide from the health information national trends survey 2012," vol. 16, no. 7, p. e172, Jul. 2014, doi: 10.2196/jmir.3117.

[33] R. Cooke and A. Papadaki, "Nutrition label use mediates the positive relationship between nutrition knowledge and attitudes towards healthy eating with dietary quality among university students in the UK," Appetite, vol. 83, pp. 297-303, Dec. 2014, doi: 10.1016/j.appet.2014.08.039.

[34] R. C. Y. Chang, "The influence of attitudes towards healthy eating on food consumption when travelling," Curr. Issues Tour., vol. 20, no. 4, pp. 369-390, Mar. 2017, doi: 10.1080/13683500.2014.890579.

[35] C. E. Caspi, G. Sorensen, S. V. Subramanian, and I. Kawachi, "The local food environment and diet: a systematic review," Health Place, vol. 18, no. 5, pp. 1172-1187, Sep. 2012, doi: 10.1016/j.healthplace.2012.05.006.

[36] C. E. Caspi, I. Kawachi, S. V. Subramanian, G. Adamkiewicz, and G. Sorensen, "The relationship between diet and perceived and objective access to supermarkets among low-income housing residents,” Soc. Sci. Med., vol. 75, no. 7, pp. 1254-1262, Oct. 2012, doi: 10.1016/j.socscimed.2012.05.014.

[37] E. Flint, S. Cummins, and S. Matthews, "Do perceptions of the neighbourhood food environment predict fruit and vegetable intake in low-income neighbourhoods?," Health Place, vol. 24, pp. 11-15, Nov. 2013, doi: 10.1016/j.healthplace.2013.07.005.

[38] P. Lally, N. Bartle, and J. Wardle, "Social norms and diet in adolescents," Appetite, vol. 57, no. 3, pp. 623-627, Dec. 2011, doi: 10.1016/j.appet.2011.07.015

[39] S. Pedersen, A. Grønhøj, and J. Thøgersen, "Following family or friends social norms in adolescent healthy eating," Appetite, vol. 86, pp. 54-60, Mar. 2015, doi: 10.1016/j.appet.2014.07.030.

[40] S. Sumaedi et al., "Factors influencing intention to follow the 'stay at home' policy during the COVID-19 pandemic," Int. J. Heal. Gov., vol. 26, no. 1, pp. 13-27, Nov. 2020, doi: 10.1108/IJHG-05-2020-0046.

[41] U. Sekaran and R. Bougie, Research methods for business: a skill-building approach, 7th editio. West Sussex: John Wiley \& Sons, 2016.

[42] B. Tennant et al., "eHealth literacy and Web 2.0 health information seeking behaviors among baby boomers and older adults," $J$. Med. Internet Res., vol. 17, no. 3, p. e70, Mar. 2015, doi: 10.2196/jmir.3992.

[43] D. Alhuwail and Y. Abdulsalam, "Assessing electronic health literacy in the state of kuwait: survey of internet users From an Arab State," J. Med. Internet Res., vol. 21, no. 5, p. e11174, May 2019, doi: 10.2196/11174.

[44] A. K. Hall, J. M. Bernhardt, V. Dodd, and M. W. Vollrath, "The digital health divide: evaluating online health information access and use among older adults," Heal. Educ. Behav., vol. 42, no. 2, pp. 202-209, Apr. 2015, doi: 10.1177/1090198114547815.

[45] D. Rahardjo, Sumardjo, D. P. Lubis, and S. Harijati, "Internet access and usage in improving students' self-directed learning in Indonesia Open University," Turkish Online J. Distance Educ., vol. 17, no. 2, pp. 30-41, Apr. 2016, doi: 10.17718/tojde.90196.

[46] J. Son, L. S. Niehm, D. W. Russell, and J. Lee, "Assessing the social media use and needs of small rural retailers: Implications for extension program support," J. Ext., vol. 57, no. 2, pp. v57-2rb2, 2019.

[47] L. K. Williams, G. Abbott, L. E. Thornton, A. Worsley, K. Ball, and D. Crawford, "Improving perceptions of healthy food affordability: results from a pilot intervention,” Int. J. Behav. Nutr. Phys. Act., vol. 11, no. 1, pp. 1-5, 2014, doi: 10.1186/14795868-11-33.

[48] W. Lu et al., "Evaluating the influence of the revised special supplemental nutrition program for women, infants, and children (wic) food allocation package on healthy food availability, accessibility, and affordability in Texas," J. Acad. Nutr. Diet., vol. 116, no. 2, pp. 292-301, Feb. 2016, doi: 10.1016/j.jand.2015.10.021.

[49] B. T. Nystrand and S. O. Olsen, "Consumers' attitudes and intentions toward consuming functional foods in Norway," Food Qual. Prefer., vol. 80, 2020, doi: 10.1016/j.foodqual.2019.103827.

[50] M. Staunton, W. R. Louis, J. R. Smith, D. J. Terry, and R. I. McDonald, "How negative descriptive norms for healthy eating undermine the effects of positive injunctive norms," J. Appl. Soc. Psychol., vol. 44, no. 4, pp. 319-330, Apr. 2014, doi: 10.1111 jasp.12223.

[51] I. Acheampong and L. Haldeman, "Are nutrition knowledge, attitudes, and beliefs associated with obesity among low-income hispanic and african american women caretakers?," J. Obes., vol. 2013, pp. 1-8, 2013, doi: 10.1155/2013/123901.

Factors influencing males' loyalty toward functional foods during the COVID-19 pandemic (Sik Sumaedi) 
[52] T. Koivumäki, S. Pekkarinen, M. Lappi, J. Väisänen, J. Juntunen, and M. Pikkarainen, “Consumer adoption of future MyDataBased preventive eHealth services: an acceptance model and survey study," J. Med. Internet Res., vol. 19, no. 12, p. e429, Dec. 2017, doi: 10.2196/jmir.7821.

[53] M. I. Zainudin, F. Haji Hasan, and A. K. Othman, "Halal brand personality and brand loyalty among millennial modest fashion consumers in Malaysia," J. Islam. Mark., vol. 11, no. 6, pp. 1277-1293, Aug. 2019, doi: 10.1108/JIMA-10-2018-0187.

[54] M. Shavanddasht and M. Allan, "First-time versus repeat tourists: level of satisfaction, emotional involvement, and loyalty at hot spring," Anatolia, vol. 30, no. 1, pp. 61-74, Jan. 2019, doi: 10.1080/13032917.2018.1498363.

[55] C. Ruiz-Mafe, J. Tronch, and S. Sanz-Blas, "The role of emotions and social influences on consumer loyalty towards online travel communities,” J. Serv. Theory Pract., vol. 26, no. 5, pp. 534-558, Sep. 2016, doi: 10.1108/JSTP-12-2014-0294.

[56] S. Mouakket and M. A. Al-hawari, "Examining the antecedents of e-loyalty intention in an online reservation environment," $J$. High Technol. Manag. Res., vol. 23, no. 1, pp. 46-57, Jan. 2012, doi: 10.1016/j.hitech.2012.03.005.

[57] B. Swoboda, B. Berg, H. Schramm-Klein, and T. Foscht, "The importance of retail brand equity and store accessibility for store loyalty in local competition," J. Retail. Consum. Serv., vol. 20, no. 3, pp. 251-262, May 2013, doi: 10.1016/j.jretconser.2013.01.011.

[58] P. Lavielle and N. Wacher, "The predictors of glucose screening: the contribution of risk perception," BMC Fam. Pract., vol. 15, no. 1, p. 108, Dec. 2014, doi: 10.1186/1471-2296-15-108.

[59] S. R. Paige, K. K. Bonnar, D. R. Black, and D. C. Coster, "Rrisk factor knowledge, perceived threat, and protective health behaviors: implications for type 2 diabetes control in rural communities," Diabetes Educ., vol. 44, no. 1, pp. 63-71, Feb. 2018, doi: $10.1177 / 0145721717747228$.

[60] V. Ahuja, "Cyber extension : a convergence of ict and agricultural developmen," Glob. Media Journal-Indian Ed., vol. 2, no. 2, pp. 1-8, 2011.

\section{BIOGRAPHIES OF AUTHORS}
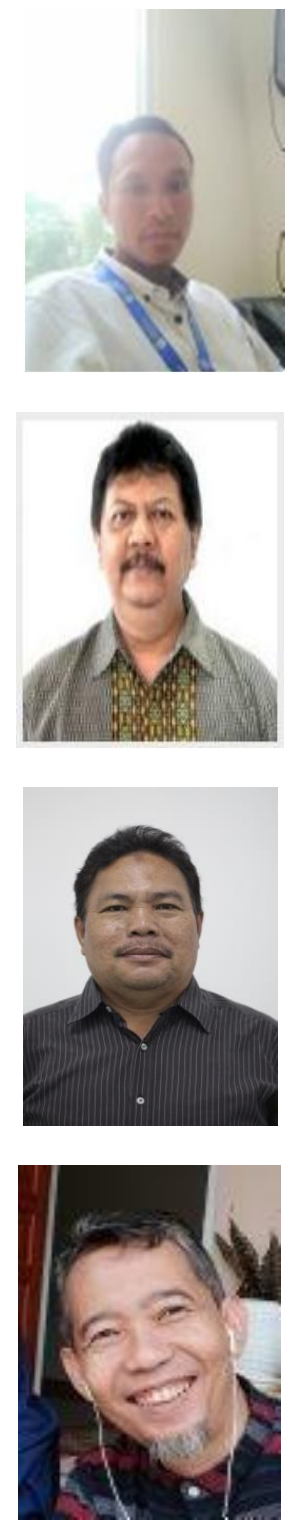

Sik Sumaedi (iD 8D SC P is a senior researcher at National Research and Innovation Agency. Public health is one of his research interests. He has published more than 50 scientific papers in national and international publications. He can be contacted at email: siks002@lipi.go.id, sik_s_01@yahoo.com

Sumardjo (iD If SC P is a Professor at Human Ecology Faculty, IPB University. He has a great experience in the field of extension education. He has published more than 200 scientific papers in national and international publications. He can be contacted at email: sumardjo252@gmail.com

Amiruddin Saleh (D) S SC P $\mathrm{P}$ is an Associate Professor at Human Ecology Faculty, IPB University. He has a great experience in the field of development communication. He has published more than 150 scientific papers in national and international publications. He can be contacted at email: amiruddin_ipb@yahoo.co.id

Agus Fanar Syukri (D) 8d SC P is a senior researcher at National Research and Innovation Agency. Public policy is his research interest. He has published more than 50 scientific papers in national and international publications. $\mathrm{He}$ can be contacted at email: agus.fanar.syukri@lipi.go.id, afanars@gmail.com 